\title{
Nonreligion and Secularity in Canada
}

\section{Introduction}

\author{
Zachary A. Munro \\ Department of Sociology and Legal Studies, University \\ of Waterloo, Waterloo, ON, Canada \\ zamunro@uwaterloo.ca
}

Sarah Wilkins-Laflamme

University of Waterloo, Waterloo, ON, Canada

sarah.wilkins-laflamme@uwaterloo.ca

This special issue of Secular Studies critically engages with key theoretical debates in nonreligion and secularity studies and contributes to a growing body of empirical research on the Canadian secular landscape. Having gained increasing attention from scholars over the past two decades, there is now a growing body of research in the subfield of nonreligion and secular studies. Notable focuses have been on nonreligious communities, such as the Sunday Assembly (e.g. Cross 2017; Smith 2017; Mortimer, Tim, and Melanie Prideaux 2018), nonreligious identities (e.g. Hacket 2014; Lanman et al. 2019; Lee 2014, 2015; Manning 2015; Sumerau and Cragun 2016; Voas and Day 2010; Zuckerman and Shook 2017), irreligious disaffiliation (e.g. Nica 2020; Thiessen and Wilkins-Laflamme 2017; Zuckerman 2012), political polarization (Baker and Smith 2015; Wilkins-Laflamme 2016), and on how the nonreligious meaningfully differ from their religious counterparts in values and life behaviors (Manning 2015; Thiessen and Wilkins-Laflamme 2020; Zuckerman 2008, 2014).

Further existing research has engaged with theoretical debates regarding the categories of 'nonreligion' and 'secularity' (Lee 2012, 2014, 2015; Quack 2014; Quack and Schuch 2017; Quack et al. 2020) and potential replacement categories, such as 'worldview' and 'meaning makings systems' (Taves 2020; Taves et al. 2018) or 'cosmic belief systems' (Baker and Smith 2015), as well as the multiplicity of secularities (Lee 2015; 2019; Taylor 2007; Wohlrab-Sahr and Burchardt 2012). The contributions made by scholars in this special issue extend this knowledge into new areas, highlighting empirical locations where nonreligion and secularity are becoming increasingly significant. Additionally, the 
articles in this issue engage with existing theoretical debates that intend to capture the various ways individuals live nonreligiously, with a special focus on the Canadian context where scholarship has remained limited to date.

The existing research on nonreligion and secularity outlined above has emerged primarily out of the United States and British contexts. Yet recent years have shown a growing interest from Canadian scholars who have undertaken significant work on their home landscape, with notable works such as Lori Beaman's and Steven Tomlins' edited volume Atheist Identities-Spaces and Social Contexts (2014); the laïcité and State secularism studies coming from Quebec by francophone scholars such as Valérie Amiraux, David Koussens, and Micheline Milot; Joel Thiessen's and Sarah Wilkins-Laflamme's None of the Above: Nonreligious Identity in the United States and Canada (2020); and recent large-scale team projects such as Nonreligion in a Complex Future ${ }^{1}$ led by Lori Beaman at the University of Ottawa. Canada is emerging as an important contributor to the growing subfield of nonreligion and secularity studies. This special issue contributes to the existing body of research, highlighting how nonreligion and secularity are becoming increasingly significant to Canadian society, and the various ways these concepts are operating within and shaping Canada, which will in turn impact how we understand them beyond this one national context.

The first article in this special issue by Ryan Cragun and Kevin McCaffree makes a wider theoretical contribution to the field by contesting the conceptual utility of 'nonreligion', and highlighting reservations of categorizing people by what they are not instead of by what they are. In pointing out that it is scholars, not everyday individuals themselves, who created the category of 'religious nones' and that the primary point of reference so far has been what this group lacks (religion), the two authors argue instead for a focus on identity and worldview to better capture the diversity and positive features that exist within nonreligion. The authors argue not only to abandon the term 'nonreligion', but also to adopt a worldview framework based on cross-culturally shared categories that span the religious/secular spectrum and beyond.

Zachary Munro takes us in another theoretical direction, by arguing not for the total abandonment of the conceptual religious/secular binary in the subfield, but instead by opening a third space for the empirical study of nonreligion which borders the religious and the secular, and where translation happens between the two. Munro explores these ideas with ethnographic research conducted on secular groups in Alcoholics Anonymous, and the individuals who

1 See www.nonreligionproject.ca. 
navigate (secular) AA spaces in the Greater Toronto Area. He argues that nonreligious individuals engage in processes of translating AA's religious content into new nonreligious forms that actively shape their experiences of addiction and recovery. Further, he illustrates how secularity operates in secular meetings as a form of power that works to regulate the inclusion and exclusion of religion and shapes its expressions among nonreligious and religious members alike.

The third article by Lori Beaman and Cory Steele highlight health, education, migration, and the environment as areas in which nonreligion has emerged as intersecting with the law in contexts of new diversity. They argue that, as Canada transitions to an increasingly (non)religious and diverse landscape, nonreligion has become a vital component in the pursuit of living well together' As the law has increasingly been forced to regulate (non)religious diversity, and as nonreligious actors increasingly challenge Canada's lasting Christian influence, the law is and will continue to shape and define nonreligion in potentially problematic ways. Given the diversity of individuals in the category of nonreligion, and the various worldviews, identities, and beliefs that characterize this group, the authors argue research into nonreligion is vital to ensure legal protections and equal participation for all citizens.

Géraldine Mossière contributes an ethnographic study on youth living in Montreal, with a specific focus on how secular cosmopolitanism and youth sociability practices open space for intercultural exchange between more and less religious subpopulations. She focuses on youth embedded in social networks that include Muslim friends, and how these social relations often engender particular affinities for a Muslim lifestyle among non-Muslim religious and nonreligious individuals. In the process, youth adopt Muslim practices into their own lifestyle, yet not always identifying as Muslim, and frame their understandings in a universalistic rhetoric. Mossière highlights the diversity of (non)religious sociability emerging from a secular cosmopolitanism, which can cultivate into positive intercultural exchanges and the development of new identities, practices, and worldviews.

State secularism is also a point of focus in this special issue, with E.-Martin Meunier's and Jacob Legault-Leclair's article that measures factors of support and opposition to Bill 21 in Quebec, a bill which bans religious symbols in some areas of the public sector. In contrast to other provincial and territorial secularisms in Canada, Quebec's is more akin to France's laïcité model of approaching religious neutrality through restricting religion in the public sphere. Counterintuitively, the authors show that support for Bill 21 is highest among francophones who self-identify as Catholic, compared with those who say they have no religion. Support for the bill declines among younger less religious cohorts in cosmopolitan areas, highlighting the influence of a dif- 
ferent secular rhetoric, one more universalizing and focused on inclusion that Mossière identifies in her research. At stake are points of polarization for Quebec's future, as tensions may arise from a declining cultural Catholicism as a means of retaining Quebec's distinct national heritage.

Christopher Raymond's article furthers the political analysis by examining how the rise of religious nones has changed voting behavior in Canada. Using data from the $1975^{-2005}$ Project Canada Surveys, he argues that although religious affiliates have largely remained stable in their voting patterns, the increase in religious nones has undercut support for the Conservative Party of Canada at the federal level and increased support for the New Democratic Party of Canada. His findings point to the increasing polarization between the religious and nonreligious in political orientation, for which the long-term implications remain unknown.

Sarah Wilkins-Laflamme concludes the special issue with a research note that identifies and explores some of the ethnic diversity of nonreligion in Canada. Wilkins-Laflamme points to the high levels of nonreligious identification across many minority and non-Western immigrant groups of 1st, 2nd, and 3 rd generation. She argues future research should expand its focus beyond White and Christian-background nonreligious individuals to other subpopulations and cultural contexts in order to gain a deeper understanding of the various ways nonreligion is shaped by socio-cultural environments.

The contributions of this special issue give us a much richer knowledge of the Canadian nonreligious and secular landscape. They also go beyond this. The articles included here contribute to growing the subfield into new areas in which nonreligion and secularity are proving to be important factors to social, political, and cultural life. The increasing visibility of the nonreligious, as well as the increasing (non)religious diversity in many locations, encourages a deeper study of what being nonreligious means, the various formations it may take, and how 'new diversity' will come to be managed. We hope you enjoy this special issue.

\section{Works Cited}

Arweck, Elisabeth. 2013. "'I've Been Christened, but I Don't Really Believe In It': How Young People Articulate Their (Non-)Religious Identities and Perceptions of (Non-) Belief." In Social Identities Between the Sacred and the Secular, edited by Abby Day, Giselle Vincett, and Christopher R. Cotter. (Surrey: Ashgate), pp. 103-126.

Beaman, Lori G., and Steven Tomlins, eds. 2014. Atheist Identities-Spaces and Social Contexts. New York: Springer. 
Cross, Katie. 2017. "The Sunday Assembly in Scotland: Vestiges of Religious Memory and Practise in a Secular Congregation." Practical Theology 10.3: 249-262.

Hackett, Chris. 2014. "Seven Things to Consider When Measuring Religious Identity." Religion 44.3: 396-413.

Lanman, Jonathan, Stephen Bullivant, Farias Miguel, and Lois Lee. 2019. Understanding Unbelief: Atheists and agnostics around the world: Interim findings from 2019 research in Brazil, China, Denmark, Japan, the United Kingdom and the United States.

Lee, Lois. 2012. "Research Note: Talking About a Revolution: Terminology for the New Field of Non-Religion Studies." Journal of Contemporary Religion, 27.1: 129-139.

Lee, Lois. 2014. "Secular or Nonreligious? Investigating and Interpreting Generic 'not Religious' Categories and Populations." Religion 44.3: 466-482.

Lee, Lois. 2015. Recognizing the Non-Religious. Reimaging the Secular. Oxford: Oxford University Press.

Lee, Lois. 2019. "Observing the Atheist at Worship: Ways of Seeing the Secular Body." In Secular Bodies, Affects and Emotions: European Configurations. Edited by Monique Scheer, Nodia Fadil, and Birgitte Schepelern Johansen. (London: Bloomsbury Academic).pp. 43-6o.

Manning, Christel. 2015. Losing Our Religion: How Unaffiliated Parents Are Raising Their Children. New York: New York University Press.

Mortimer, Tim and Melanie Prideaux. 2012. "Exploring Identities Between the Religious and the Secular through the Attendees of an Ostensibly 'Atheist Church." Religion 48.1: 64-82.

Nica, Andreea A. 2020. "Leaving My Religion: How Ex-Fundamentalists Reconstruct Identity Related to Well-Being." Journal of Religion and Health 59.4: 2120-2134.

Quack, Johannes. 2014. “Outline of a Relational Approach to 'Nonreligion.'” Method \& Theory in the Study of Religion 26.4-5: 439-469.

Quack, Johannes, and Cora Schuh, eds. 2017. Religious Indifference: New Perspectives from Studies on Secularization and Nonreligion. Cham: Springer.

Quack, Johannes, Cora Schuh, and Susanne Kind. 2020. The Diversity of Nonreligion: Normativities and Contested Relations. Oxon: Routledge.

Smith, Jesse M. "Can the Secular Be the Object of Belief and Belonging? The Sunday Assembly." Qualitative Sociology, 40.1: 83-109.

Taves, Ann. 2018. "What Is Nonreligion? On the Virtues of a Meaning Systems Framework for Studying Nonreligious and Religious Worldviews in the Context of Everyday Life." Secularism \& Nonreligion 7.1.

Taves, Ann, Egil Asprem, and Elliott Ihm. 2018. "Psychology, Meaning Making, and the Study of Worldviews: Beyond Religion and Non-Religion." Psychology of Religion and Spirituality, 10.3: 207-217.

Taylor, Charles. 2007. A Secular Age. Cambridge, MA: University Press. 
Thiessen, Joel, and Sarah Wilkins-Laflamme. 2017. "Becoming a religious none: Irreligious Socialization and Disaffiliation." Journal for the Scientific Study of Religion, 56.1 : $64-82$.

Thiessen, Joel, and Sarah Wilkins-Laflamme. 2020. None of the Above: Nonreligious Identity in the United States and Canada. New York: New York University Press.

Sumerau, Edward J., and Ryan T. Cragun. 2016. “I Think Some People Need Religion': The Social Construction of Nonreligious Moral Identities." Sociology of Religion: A Quarterly Review 77.4: 386-407.

Wilkins-Laflamme, Sarah. 2016. “The Changing Religious Cleavage in Canadians' Voting Behaviour." Canadian Journal of Political Science 49.3: 499-518.

Wohlrab-Sahr, Monika, and Marian Burchardt. 2012. "Multiple Secularities: Toward a Cultural Sociology of Secular Modernities." Comparative Sociology 11.6: 875-9o9.

Zuckerman, Phil. 2008. Society Without God: What the Least Religious Nations Can Tell Us About Contentment. New York: New York University Press.

Zuckerman, Phil. 2012. Why People Reject Religion. Oxford: Oxford University Press.

Zuckerman, Phil. 2014. Living the Secular Life: New Answers to Old Questions. New York: Penguin Press.

Zuckerman, Phil, and John R. Shook, eds. 2017. The Oxford Handbook of Secularism. New York: Oxford University Press. 